Historia Slavorum Occidentis

2017, nr 3 (14)

ISSN 2084-1213

DOI: $10.15804 /$ hso170306

Марта ОНИСьків $(\Lambda$ ьвів $)$

\title{
Komunikatywna efektywność uniwersałów królewskich w ostatnim trzydziestoleciu XVII w. (na podstawie ksiąg relacyjnych grodzkich województwa ruskiego)
}

Słowa kluczowe: Uniwersał królewski, wczesnonowożytna Rzeczypospolita, komunikatywna efektywność

Keywords: Royal universal, early modern Polish-Lithuanian Commonwealth, communicative efficiency

Abstract: Royal universal was an official document, which was used for mass communication in the early modern Polish-Lithuanian Commonwealth. The document was an answer to the informative needs, which early modern polish society had. The level of communicative efficiency of the royal universal was significant.

Głównym celem uniwersału królewskiego w I Rzeczypospolitej było rozpowszechnienie informacji wśród szerokiego grona osób, więc dokument ten był swoistym informatorem i elementem komunikacji masowej. Pod pojęciem komunikacji masowej rozumiemy proces „rozpowszechnienia od centrum, określonego jako źródło (w naszym przypadku to monarcha - M.O.), treści informacji podanej w znakach

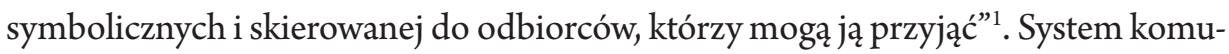
nikacyjny formuje sieć, „w której pewne wyrażenie informacji - najczęściej słowne

1 A. Filipek, Proces komunikowania jako element kultury społecznej, [w:] Bezpieczeństwo człowieka a komunikacja społeczna, t. 2: Aspekty filozoficzne i polityczne, Siedlce 2011, s. 131. 
- dąży od źródła do celu”; może on być różnych rodzajów i zależy od ilości osób biorących udział w komunikacji ${ }^{2}$. Chcąc zrozumieć rolę uniwersału królewskiego w systemie komunikacyjnym wczesnonowożytnej Rzeczypospolitej, należy zwrócić uwagę na jego definicję: „to rodzaj dokumentacji kancelarii koronnej, którą używano w celu: publikacji treści odrębnych konstytucji sejmowych oraz różnego rodzaju dyplomów; zwołania i zawiadomienia o terminie i miejscu obrad sejmikowych (najczęściej przedsejmowych); ogłoszenia «pospolitego ruszenia»; opublikowania orzeczeń króla, dotyczących jego kompetencji królewskich” ${ }^{3}$ Oprócz tego, w obszernej i znaczącej narracji tego dokumentu często obwieszczano o różnych wydarzeniach $\mathrm{w}$ dziejach państwa. To przyczyniło się do wyodrębnienia w strukturze uniwersału, oprócz typowych formuł ówczesnego aktu, klauzuli końcowej publikacji, która zawierała wymóg ogłaszania treści dokumentu we wszystkich niezbędnych miejscach i była główną cechą uniwersału jako aktu informacyjnego ${ }^{4}$.

Chcąc dokładniej zrozumieć zasady rozpowszechnienia informacji masowej, należy najpierw odpowiedzieć na pytania: Jaką była komunikacja masowa w ostatnim trzydziestoleciu XVII w.? Czy istniały alternatywne środki przekazu informacji masowej? Jakie miejsce zajmowały uniwersały królewskie w systemie komunikacji masowej województwa ruskiego? Można stwierdzić, że komunikacja masowa musiała łączyć większą część ówczesnego społeczeństwa, nie tylko szlachtę, którą współcześni utożsamiali z ogółem społeczeństwa ${ }^{5}$. Według badaczy ówczesna szlachta charakteryzowała się cechami informacyjnej otwartości ${ }^{6}$ lub nawet więcej - w środowisku dworskim i magnackim (wśród szlachty, uczestniczącej w życiu publicznym) był tzw. głód informacyjny ${ }^{7}$. Jednakże w historiografii nie zaprzecza się tezie, że niższe warstwy społeczne również dążyły do wymiany lub komentowania aktualnych wiadomości politycznych ${ }^{8}$ (chociaż z całą pewnością jest to trudne do udowodnienia

2 W. Domachowski, S. Kowalik, J. Miluska, Z zagadnień psychologii społecznej, Warszawa 1984, s. 108.

3 М. Ониськів, Королівський універсал - інформаційний документ Коронної канцелярії останньої чверті XVII століттл (на матеріалах реляційних книг Аьвівського, Перемишльського, Сяноцького, Галищького та Теребовельського ґродських урядів), Вісник Аьвівського Університету. Серія: Книгознавство, бібліотекознавство та інформаційні технології 9 (2014), s. 152.

4 Tamże, s. 152.

5 U. Augustyniak, Informacja i propaganda w Polsce za Zygmunta III, Warszawa 1981, s. 85.

6 Tamże, s. 92.

7 K. Maliszewski, $W$ kręgu staropolskich wyobrażeń o świece, Lublin 2006, s. 58.

8 U. Augustyniak, Informacja i propaganda, s. 138. 
ze względu na brak danych źródłowych) ${ }^{9}$. Informacje, którymi najczęściej interesowało się społeczeństwo Rzeczypospolitej, były różnorodne. W sposób oczywisty największe zainteresowanie budziły sprawy związane z obradami sejmu jako głównego organu ustawodawczego. Dowodem na to jest wydanie w latach 1696-1697 dwóch warszawskich gazet - „Wiadomości z Warszawy” i „Dyaryusz Sejmu Electionis”, które możemy nazwać „sejmowymi”. Przez te czasopisma władza przekazywała obywatelom informację o rozwoju sytuacji w trakcie sejmów, głównie z okresu bezkrólewia - konwokacyjnego z 1696 r. oraz elekcyjnego z 1697 r. ${ }^{10}$ Swoistą reakcją na zapotrzebowanie informacyjne ówczesnego społeczeństwa było udoskonalenie umiejętności zbierania i wykorzystywania wiadomości w specjalnych informatorach, przez dysponentów (źródło) informacji - zwykle była to władza państwowa ${ }^{11}$. Dowodem tego może być wydanie w 1661 r. pierwszej polskiej gazety „Merkuriusz Polski”, która ukazywała się przez 41 tygodni. Chociaż trzeba podkreślić, że był to jeden z wielu środków polityczno-propagandowych finansowany przez dwór królewski, a nie odpowiedź na społeczne zapotrzebowanie obywateli Rzeczypospolitej ${ }^{12}$.

Głównym, nieoficjalnym źródłem komunikacji masowej były tak zwane „gazety ulotne”. To „pisane prozą lub wierszami druki (lub rękopisy - M.O.) małej objętości, w których mieściła się jedna lub kilka aktualnych wiadomości z kraju i zagranicy, głównie treści politycznej, wojskowej lub religijnej. Zwykle ich wydanie było inspirowane ważnymi, nietypowymi wydarzeniami, które mogły wywołać szersze zainteresowanie"13. Oprócz tego, przekazywaniem informacji zajmowali się tzw. profesjonalni informatorzy. Były to osoby o różnym statusie społecznym, które zajmowały się organizowaniem obiegu informacji i komunikacji między dworem królewskim z jednej strony, a dworami magnaterii, szlachtą ${ }^{14} \mathrm{i}$ dużymi miastami z drugiej ${ }^{15}$.

9 Tamże, s. 84.

10 K. Zawadzki, Dwie nieznane gazety „sejmowe” z 1696 i 1697 r., Rocznik Warszawski 27 (1998), s. 63.

11 M. Ujma, Duże miasta Rzeczypospolitej a obieg informacji w świetle relacji francuskich $z$ XVII i XVIII wieku, [w: ] Komunikacja i komunikowanie w dawnej Polsce, red. K. Stępnik, M. Rajewski, Lublin 2008, s. 105.

12 J. Łojek, Prasa polska w latach 1661-1831, [w:] Historia prasy polskiej, t. 1: Prasa polska w latach 1661-1864, red. J. Łojek, Warszawa 1976, s. 13-15.

13 E. Gruszczyńska, Dawne polskie przekłady prasowe. Informacja - perswazja - manipulacja, Warszawa 2012, s. 15.

14 U. Augustyniak, Informacja i propaganda, s. 175-179.

15 K. Maliszewski, Mieszczańskie formy i metody komunikacji społecznej w wielkich miastach Prus 
Funkcje tych źródeł informacji w systemie komunikacji masowej województwa ruskiego w ostatnim trzydziestoleciu XVII w. były ograniczone: nawet we Lwowie poziom wydawania "gazet ulotnych” pozostawał niski. Miało tu miejsce niewielkie zainteresowanie mediami, chociaż wśród mieszkańców pojawiały się „gazety ulotne”, dostarczane ze stolicy ${ }^{16}$. Lwów jako centrum województwa ruskiego był oczywiście jednym z głównych ośrodków pozyskiwania i przekazywania informacji dla „gazet ulotnych", które wydawano w innych częściach państwa ${ }^{17}$. Pozytywny wpływ na ten proces miało powstanie we Lwowie poczty w $1629 \mathrm{r}^{18}$, np. lwowski mistrz pocztowy Fabian Ziwert ${ }^{19}$ był nie tylko korespondentem („informatorem profesjonalnym”) biskupa Andrzeja Chryzostoma Załuskiego, ale redagował równocześnie gazety rękopiśmienne (głównie dla mistrza pocztowego z Torunia), dostarczał do Warszawy informacje o wydarzeniach w południowo-wschodnich województwach Rzeczypospolitej. Dopiero ze stolicy informacja rozpowszechniała się na inne regiony kraju ${ }^{20}$. Informacyjna specyfika województwa ruskiego polegała na tym, że z tych terenów „nigdy nie słyszeć nic dobrego”21.

Oficjalnymi, podstawowymi środkami przekazu informacji masowej we wczesnonowożytnej Rzeczypospolitej były wspomniane już królewskie uniwersały i instrukcje (legacje) dawane posłom królewskim na sejmiki przedsejmowe ${ }^{22}$. Chociaż zawartość uniwersałów zwykłe była o wiele skromniejsza od legacji23 ${ }^{23}$ zatrzymamy

Królewskich w XVII-XVIII wieku, Zapiski Historyczne Poświęcone Historii Pomorza i Krajów Bałtyckich 57 (1992), z. 4, s. 42.

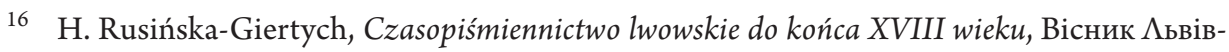
ського Університету. Серія: Книгознавство, бібліотекознавство та інформаційні технології 2 (2007), s. 77.

17 K. Maliszewski, W kręgu staropolskich wyobrażeń o świece, Lublin 2006, s. 31.

18 Tenże, Komunikacja społeczna w kulturze staropolskiej, Toruń 2001, s. 31.

19 F. Ziwert był sekretarzem królewskim, jako urzędnik państwowy to on dostarczył dwa ogólnopaństwowe uniwersały do lwowskiego grodu (Центрацьний державний історичний архів України у Аьвові / Centralne Państwowe Archiwum Historyczne Ukrainy we Lwowie (dalej - CPAH Ukrainy we Lwowie), f. 9 (Sąd grodzki lwowski), op. 1, spr. 453, s. 907-909; spr. 463, s. 1652-1654).

20 K. Maliszewski, Problematyka turecka $w$ polskich gazetach pisanych $w$ czasach panowania Jana III Sobieskiego, [w: ] Studia z dziejów epoki Jana III Sobieskiego, red. K. Matwijowski, Wroclaw 1984, s. 100.

21 U. Augustyniak, Informacja i propaganda, s. 87-88.

22 K. Maliszewski, Komunikacja społeczna, s. 46.

23 H. Olszewski, Sejm w dawnej Rzeczypospolitej. Ustrój i idee, t. 1: Sejm Rzeczypospolitej epoki 
się na dokładnej charakterystyce ich treści. Zaletą uniwersałów była bardziej zróżnicowana, „uniwersalna” tematyka, duża prędkość przekazu informacji oraz pozytywne warunki dla szerszego dostępu do ich treści.

Przed omówieniem efektywności komunikacyjnej uniwersałów królewskich warto przypomnieć definicję tego pojęcia. Komunikatywna efektywność występuje wtedy, gdy „możliwość zbliżenia się do problemu tworzy pewną formę językowego zachowania, która zależy od tego, kto mówi, do kogo, w jakich sytuacjach i w jakim celu”24. Sprecyzujmy po kolei każdą część komunikatywnej efektywności. Pierwsza część - „kto mówi”. „Autorem” i faktycznym wystawcą uniwersałów był sam król. Głównym celem ich wydania stało się rozpowszechnienie informacji oficjalnej, co zwiększało wartość informacyjną uniwersałów „w oczach” społeczeństwa, które chciało mieć informację „od pierwszej osoby” ${ }^{25}$. Oprócz tego duże zainteresowanie budziły właściwe dokumenty autentyczne, potwierdzone podpisem i pieczęcią króla, więc $\mathrm{z}$ wiadomościami prawdziwymi ${ }^{26}$. Tu ważne znaczenie miał królewski podpis, zwykle umieszczony pod tekstem uniwersału z lewej strony ${ }^{27}$, jego nieobecność była rzadkością ${ }^{28}$. Ponadto większość uniwersałów potwierdzali swoimi podpisami rów-

oligarchii (1652-1763). Prawo - praktyka - teoria - programy, Poznań 2002, s. 59. Chociaż nie zawsze tak bywało: np. forma i treść legacji królewskiej z 1690 r. nie bardzo różniła się od uniwersału sejmikowego (M. Mróz, Ostatnie zwycięstwo parlamentarne króla. Sejm 1690 roku, [w:] Z dziejów i tradycji srebrnego wieku. Studia i materiaty, red. J. Pietrzak, Wrocław 1990, s. 103).

24 W. Bryła, Komunikacja staropolska w "krzywym zwierciadle” widziana, [w:] Komunikacja i komunikowanie w dawnej Polsce, red. K. Stępnik, M. Rajewski, Lublin 2008, s. 255.

25 S. Roszak, Formy opisu rzeczywistości w szlacheckich księgach „silva rerum”, [w:] Staropolski ogląd świata. Materiaty z konferencji, Wroctaw 23-24 października 2004 r., red. B. Rok, F. Wolański, Wrocław 2004, s. 170.

26 U. Augustyniak, Informacja i propaganda, s. 47.

27 CPAH Ukrainy we Lwowie, f. 9, op. 1, spr. 430, s. 994-998.

28 Tylko w dwóch przypadkach ( $w$ analizowanym materiale) nie było podpisów króla. Pierwszy taki uniwersał wydano $16 \mathrm{~V} 1671$ r., jego treść dotyczyła ogłoszenia trzecich wici, którymi król wzywał do zebrania wojska 13 lipca pod Lwowem; 12 czerwca zwołał sejmik w Wiszni, na którym miała być rozstrzygnięta sprawa zwrotu długów; ogłaszano o zebraniu piechoty; król zawiadamiał również, że 600 tysięcy złotych, które Trybunał Radomski wydzielił dla zapłaty wojskom autoramentu cudzoziemskiego, będą skierowane do tych jednostek, które od dłuższego czasu są wierne królowi (tamże, f. 9, op. 1, spr. 425, s. 2023-2025). Inny uniwersał „bez podpisu” informował o pomyślnej koronacji króla Jana III, dokument wydano 5 II 1676 r., w czasie działalności sejmu koronacyjnego (2 II-14 III 1676 r. [W. Konopczyński, Chronologia sejmów polskich 1493-1793, Archiwum Komisji Historycznej, seria 2, t. 4, nr 3, Kraków 1948, s. 157]). Te uniwersały podpisali ówcześni regenci kancelarii (CPAH Ukrainy we Lwowie, f. 5 [Sąd grodzki halicki], op. 1, spr. 177, s. 247-251; f. 9, op. 1, spr. 425, s. 2023-2025; f. 13 (Sąd grodzki przemy- 
nież funkcjonariusze kancelarii koronnej: głównie sekretarze królewscy ${ }^{29}$ i regenci (kierownicy techniczni) ${ }^{30}$. Brak podpisów kanclerza lub podkanclerzego można wyjaśnić tym, że uniwersał nie tworzył nowego prawa, a tylko deklarował stan obecny ${ }^{31}$. Najczęściej treść potwierdzano większą lub mniejszą pieczęcią kancelarii koronnej. Umieszczano ją pod tekstem pośrodku, między podpisami króla i urzędnika (podpis urzędnika umieszczony był po prawej stronie pieczęci, w dolnym rogu) ${ }^{32}$. O wiele rzadziej spotykamy pieczęć pokojową. Według ówczesnego ustawodawstwa stosowano ją wyłącznie w pilnej potrzebie potwierdzenia dokumentu, kiedy nie było możliwości uzyskania pieczęci od kanclerzy ${ }^{33}$. Czasowe prawo do korzystania z pokojowej pieczęci przysługiwało królowi Janowi III na początku jego rządów, ze względu na jego udział w działaniach wojennych ${ }^{34}$.

ski), op. 1, spr. 420, s. 586-590; f. 15 (Sąd grodzki sanocki), op. 1, spr. 188, s. 229-232), a drugi z nich również i kanclerz (tamże, f. 5, op. 1, spr. 177, s. 247-251; f. 13, op. 1, spr. 420, s. 586-590; f. 15, op. 1, spr. 188, s. 229-232).

29 Przynależność sekretarzy królewskich do kancelarii koronnej potwierdza się tym, że ich podpisy są obok większej lub mniejszej pieczęci kancelaryjnej - widocznie rodzaj pieczęci zależał od przynależności sekretarza do większej lub mniejszej kancelarii koronnej (CPAH Ukrainy we Lwowie, f. 9, op. 1, spr. 463, s. 1941; f. 13, op. 1, spr. 457, s. 2728-2729; f. 15, op. 1, spr. 197, s. 1148-1150).

30 Tamże, f. 5, op. 1, spr. 170, s. 593-594; spr. 174, s. 1669-1670; f. 9, op. 1, spr. 423, s. $1711-$ -1713; spr. 424, s. 366-368; spr. 429, s. 2009-2011; f. 13, op. 1, spr. 409, s. 195-198; spr. 414, s. 1221-1223; spr. 416, s. 2356-2358; Archiwum Państwowe w Lublinie (dalej - APL), Księgi Grodzkie Chełmskie, Relationes, manifestationes, oblatae (dalej - KGCh, RMO), 89, s. 424-427 ; 90, s. 338-340.

31 Nie odnotowano informacji, czy kanclerz lub podkanclerzy mieli pierwszeństwo w pieczętowaniu czystopisów uniwersałów. Ich „monopol” na potwierdzanie aktów monarszych upowszechnił się dopiero w XIV w. (W. Chorążyczewski, Początki kancelarii pokojowej za Jagiellonów, [w:] Polska kancelaria królewska czasów nowożytnych: między władza a społeczeństwem. Materiaty konferencji naukowej, Toruń 18 kwietnia 2002 roku, red. W. Chorążyczewski, W. Krawczuk, Warszawa 2008, s. 36). Kanclerz lub podkanclerzy mogli przystawić pieczęć na dokumentach królewskich lub odmówić w przypieczętowania, nie pytając o zezwolenie króla (П. Кулаковський, Канцелярія Руської [Волинської] метрики 1569-1673 рр.: студіл з історії українського

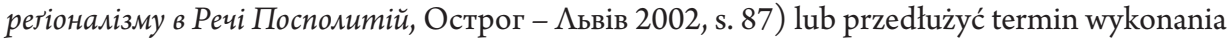
tej procedury (H. Palkij, Problem komunikacji między kanclerzem wielkim koronnym a dworem w procesie tworzenia dokumentu w czasach Augusta II, Studia Archiwalne 2 (2006), s. 102).

32 Archiwum Główne Akt Dawnych w Warszawie (dalej - AGAD), zesp. 2 (Zbiór dokumentów papierowych), sygn. 5 .

33 W. Krawczuk, Kancelaria pokojowa za Wazów, [w:] Polska kancelaria królewska, s. 49.

34 M. Hlebionek, Nowożytne pieczęcie królów polskich, [w: Polska kancelaria królewska, s. 57. 
Ze względu na fakt, że wystawcą uniwersałów był sam król, pozytywnie zwiększało to możliwości rozpowszechnienia ich zawartości, na poszerzenie kręgu adresatów. Treść dokumentu promowano nie tylko siłami osób prywatnych, lecz również wszystkimi środkami, którymi dysponował aparat państwowy oraz instytucje publiczne (zwłaszcza przez urzędy grodzkie). Uniwersały dostarczano staroście ${ }^{35}$, a później wpisywano w formie oblaty (dosłownego kopiowania) do ksiąg grodzkich. Wpisu tego dokonywali podpiskowie kancelarii grodzkiej ${ }^{36}$, jednocześnie dodając nagłówek, początkową i końcową formułę kancelaryjną ${ }^{37}$. Można dyskutować na temat poziomu efektywności komunikacyjnej uniwersału królewskiego na terenie województwa ruskiego w chwili jego przyjęcia przez urząd grodzki. Ówczesne prawo uznawało, że każdy zainteresowany szlachcic czy mieszczanin może przyjść do grodu i zażądać uzyskania potrzebnej informacji ${ }^{38}$. Na realizację tej zasady pozytywny wpływ miało przyznanie wieczności grodom województwa ruskiego w końcu XV w. Od tego czasu akty przechowywano w kancelarii, a nie prywatnie $\mathrm{u}$ starosty lub w jego archiwum rodzinnym ${ }^{39}$. Przechowywano je w skrzyniach, które zamykano na jeden lub trzy zamki, dlatego dla ich otwarcia niezbędna była obecność wszystkich urzędników sądowych lub ich komorników (sług) z kluczami ${ }^{40}$. Księgi sądowe układano według chronologii, a wpisy do nich wprowadzano w momencie otrzymania. Poszukiwać informacji można było w obecności urzędnika kancelarii. To właśnie on miał dostarczyć krótki, sensowny i dokładny, zawierający wszystkie poprawki, wyciąg (ekstrakt) z dokumentu. Jeśli informacji nie znaleziono, wtedy urząd miał wydać świadectwo, potwierdzające, że kwerenda nie powiodła się przez zniszczenie ksiąg lub ich poszczególnych stron, albo po prostu przez brak szukanego wpisu ${ }^{41}$. Jednak w praktyce urzędowej tej reguty

35 О. Купчинський, Земські і эродські судово-адміністративні фонди Аьвова, Київ 1998, s. 17.

36 Tamże, s. 19.

37 Formuły kancelaryjne mogły zawierać następujące informacje: nagłówek; określenie osoby, która dostarczyła dokument do grodu; krótka informacja o treści; sposób zaświadczenia (formuła początkowa); miejsce przechowywania oryginału; relacja woźnego generalnego koronnego o opublikowaniu uniwersału (formuła końcowa).

38 J. Łosowski, Kancelaria grodzka chetmska od XV do XVIII wieku. Studium o urzędzie, dokumentacji, jej formach i roli w życiu społeczeństwa staropolskiego, Lublin 2004, s. 319.

39 П. Захарчишина, Писарі й архівісти земських та эродських канцелярій на західноукраїнських землях у XV-XVIII cm., Архіви України 1 (1969), s. 17-18.

40 P. Dąbkowski, Palestra i księgi sądowe ziemskie i grodzkie w dawnej Polsce, Pamiętnik Historyczno-Prawny 3 (1926), z. 2, s. 48-49.

41 Tamże, s. 77-79. 
nie zawsze przestrzegano. Często pojawiały się obiektywne przeszkody w uzyskaniu informacji z ksiąg, czasami na przeszkodzie stawał personel kancelarii, który nie przestrzegał zasad prawidłowego przechowywania dokumentów. Przed 1764 r. większość dokumentacji była rozproszona i pozostawała w postaci odrębnych dokumentów. Regenci również nie przestrzegali obowiązku nadzoru nad aktami - zdarzało się, że kanceliści dawali klucze do archiwum osobom, które potrzebowały ekstraktu z dokumentu i nie byli obecni przy kwerendzie) ${ }^{42}$. Było to sprzeczne z konstytucją sejmową z 1613 r. Według niej pisarz grodzki, który zaniedbał archiwum, musiał odpowiadać przed trybunałem, z tym, że za odpowiedzialnego uznawano również starostę ${ }^{43}$. Ograniczanie dostępu do aktów grodzkich zależało również od przyczyn praktycznych, np. w 1671 r. doszło do zawalenia gmachu kancelarii grodu lwowskiego i w ciągu kolejnego dziesięciolecia ten problem nie został rozwiązany ${ }^{44}$.

Oprócz problemów z dostępem do dokumentów i specyficznych warunków ich przechowywania, niezbyt regularny był również proces oblatowania uniwersałów do akt grodzkich. Chociaż w księgach z terenu województwa ruskiego udało się odnaleźć sporo uniwersałów królewskich, lecz przypuszczamy, że jest to tylko pewna część wszystkich ogólnopaństwowych / priorytetowych uniwersałów ${ }^{45}$, wysłanych do miejscowych grodów. Po pierwsze, czasami proces oblaty był rozpoczęty, lecz nie skończony: w aktach mieści się tylko nagłówek lub początkowe formuły wpisu uniwersału, a w księdze pozostawiono puste miejsce, którego nigdy później nie uzupełniono. Po drugie, niektóre uniwersały ogólnopaństwowego znaczenia z niewiadomych przyczyn nie były oblatowane wszędzie, a jedynie w niektórych grodach, np. uniwersał - wici, którym wzywano na sejmik wojskowy w Wiszni, został wpisany do akt grodzkich przemyskich i sanockich ${ }^{46}$. Natomiast nie ma o nim wzmianki w księgach lwowskich, chociaż właśnie do grodu lwowskiego miał być wpisany w pierw-

\footnotetext{
42 P. Dąbkowski, Uwagi o urządzeniu ksiąg sądowych w dawnej Polsce, Lwów 1918, s. 17-22.

43 S. Kutrzeba, Historja źródet dawnego prawa polskiego, t. 1, Lwów-Warszawa-Kraków 1926, s. 380 .
}

44 P. Dąbkowski, Księgi sądowe lwowskie w dawnej Polsce, Studia nad Historią Prawa Polskiego 16 (1937), z. 1, s. 6.

45 Uniwersał królewski wydawano przy potrzebie rozpowszechnienia jakiejś informacji lub jako odpowiedź na pewien wymóg prawny. Jeśli informacja miała ogólnopaństwowe znaczenie, wtedy dokument wydawano w imieniu króla. Uniwersały takie uważamy za ogólnopaństwowe/ priorytetowe.

46 CPAH Ukrainy we Lwowie, f. 13, op. 1, spr. 417, s. 2069-2074; f. 15, op. 1, spr. 186, s. 1249-1255 . 
szej kolejności. Ponadto czasami uniwersały byli oblatowane zbyt późno, informacje i instrukcje zawarte w nich były już nieaktualne. Podobne przypadki znamy w przypadku innych uniwersałów - wici $^{47}$ oraz uniwersałów sejmowych. Te ostatnie często oblatowano po sejmiku ${ }^{48}$, lub jeden ${ }^{49}, \mathrm{dwa}^{50}$ lub trzy ${ }^{51}$ dni przed nim.

W urzędzie grodzkim nie tylko oblatowano uniwersały królewskie, lecz również przechowywano je. Do funkcji informacyjnych grodów zaliczamy, po pierwsze ogłoszenie treści uniwersału przez woźnego generalnego koronnego. Urzędnicy w ostatecznych formułach wpisu zwykłe zaznaczali, gdzie miała miejsce ta czynność - na zamku, w mieście, na rynku ${ }^{52}$, wskazując również na obecność tam wielu ludzi ${ }^{53}$ wywodzących się z różnych grup społecznych i obojga płci ${ }^{54}$. Woźny koronny ogłaszał treść uniwersału królewskiego, uroczyście czytając go przy dźwiękach trąb i bębnów ${ }^{55}$, w dni, kiedy w mieście było dużo odwiedzających ludzi ${ }^{56}$. Prawdopodobnie ogłaszano nie pełną treść dokumentu ze wszystkimi klauzulami, lecz opowiadano główny cel jego wydania ${ }^{57}$. Po drugie, w kancelarii grodzkiej pisano kopie:

47 Akta grodzkie i ziemskie z czasów Rzeczypospolitej polskiej z archiwum tak zwanego bernardyńskiego we Lwowie, t. 24, oprac. A. Prochaska, Lwów 1931, s. 314.

48 CPAH Ukrainy we Lwowie, f. 9, op. 1, spr. 426, s. 2597-2599, f. 13, op. 1, spr. 414, s. 1439-1442.

49 Tamże, f. 15, op. 1, spr. 200, s. 45-46.

50 Tamże, f. 9, op. 1, spr. 427, s. 1579-1582; spr. 454, s. 2486-2488; f. 13, op. 1, spr. 414, s. 1221-1223 (uniwersał wydano w Jaworowie, 10 dni przed tym).

51 Tamże, f. 9, op. 1, spr. 452, spr. 3100-3102.

52 Z tego powodu kupcy jarmarczni oraz kobiety zajmujący się handlem na targach byli pierwszymi informatorami o nowościach z sejmu (U. Augustyniak, Informacja i propaganda, s. 41).

53 CPAH Ukrainy we Lwowie, f. 13, op. 1, spr. 406, s. 142-144.

54 Tamże, f. 13, op. 1, spr. 461, s. 2086-2088.

55 l[ite]ras $p[$ rae] inscr [ip]tas universales Sacra[e] Regia[e] Ma[ies]t[a]tis in locis publica[ti]onum solitis, convocata $[\mathrm{m}]$ per tubam hominum communitate, alta sua $p[$ rae] conica voce publicasse (Tamże, f. 9, op. 1, spr. 427, s. 1579-1582; spr. 434, s. 991-993; f. 13, op. 1, spr. 461, s. 2086-2088).

56 U. Augustyniak, Informacja i propaganda, s. 46.

57 Potwierdzeniem tego jest cytat z relacji woźnego: „Raczcie $\mathrm{W}$ [asze] M[iłości] wiedzieć, iż jest wola króla J[ego] $\mathrm{M}$ [iło] sci, pana naszego miłościwego, według tego uniwersału, ażeby wszyscy kupcy, tak koronni, jako i cudzoziemscy, w województwie ruskim i we wszystkich jego miastach, miasteczkach, wsiach dziedzicznych i królewskich, a osobliwie we Lwowie, Samborze, Przemyślu, Jarosławiu y w innych, pensyją od towarów swoich wszelkich którychkolwiek i od bydła, od koni, od sum pieniężnych, od każdego po groszu pod przysięgą do rąk panów starszych strzelców miasta Lwowa, abo ich egzaktorów, tak pod czas jarmarku, jako i bez jarmarku, płacili i oddawali, pod winami w tymże przywileju i uniwersale, nie sprzeciwiacz się, opisanemi" (CPAH Ukrainy we Lwowie, f. 9, op. 1, spr. 439, s. 388-392). 
transumpty (dosłowne powtórzenie tekstu potwierdzonego władzą państwową lub kościelną) $)^{58}$ - te najczęściej wysyłano do innych grodów ${ }^{59}$; lub widymusy (kopie całego tekstu uniwersału, wydanego w imieniu instytucji państwowej $)^{60}$ - prezentowano je w miejscach publicznych ${ }^{61}$, wysyłano do parafii ${ }^{62}$, gdzie ogłaszano ich zawartość $\mathrm{z}$ ambony i przytwierdzano do drzwi kościołów ${ }^{63}$. Odpisy z uniwersałów sporządzano również dla szlachty, zwłaszcza dla tych jej przedstawicieli, którzy rzadko bywali w miastach powiatowych ${ }^{64}$. Najczęściej w ten sposób wysyłano uniwersały sejmikowe ${ }^{65}$, oczywiście przez woźnego lub przedstawicieli szlachty ${ }^{66}$. Bez udziału grodu treść uniwersałów ogłaszano na zjazdach ${ }^{67}$, przy drogach publicznych (kiedy już poinformowani ludzie opowiadali treść dokumentu innym podróżnym) ${ }^{68}$ lub bezpośrednio po dostarczeniu dokumentu od jednego adresata do drugiego (np. znamy uniwersal, którym ogłoszono miejsce zebrania się chorągwi - miał być przekazywany od oddziału do oddziału) ${ }^{69}$. Generalnie rzecz biorąc, różnorodność spo-

58 Dyplomatyka wieków średnich, oprac. K. Maleczyński, M. Bielińska, A. Gąsiorowski, Warszawa 1971, s. 21.

59 Dokładniej na ten temat: М. Ониськів, Місто Аввів як простір дяя поширення урядової інформауії серед населення Руського воєводства останньої чверті XVII cm. (на підставі королівських універсалів), [w:] Аввів: місто - суспільство - культура: Збірник наукових праць, т. 10: Аввів / Lwów / Lemberg як міські простори: уявлення, досвіди, практики, реА. О. Аркуші, О. Вінниченка, М. Муарого, част. 2 [w druku].

60 Dyplomatyka wieków średnich, s. 21. Kopia była wizualnym powtórzeniem oryginału: tekst pisano na identycznym arkuszu papieru; tak samo umieszczano tekst; wzmiankę o sposobach uwierzytelnienia oryginału pisano w tym miejscu, gdzie w oryginale była pieczęć i podpis. Kopia odróżniała się od oryginału tym, że nie zatwierdzano jej podpisem i pieczęcią króla, natomiast w dolnej części z obu stron pieczęci po polsku notowano nazwę uniwersału oraz dane osoby, która dostarczyła go do grodu (AGAD, zesp. 354 [Archiwum Radziwiłłów], dział II [Dokumenty historyczne], sygn. 1785, 1787).

61 CPAH Ukrainy we Lwowie, f. 9, op. 1, spr. 429, s. 1952; f. 13, op. 1, spr. 416, s. 2142-2145.

62 Tamże, f. 5, op. 1, spr. 169, s. 1676-1679; f. 9, op. 1, spr. 423, s. 1711-1713, s. 2311; f. 13, op. 1, spr. 409, s. 195-198; APL, KGCh, RMO, 89, s. 424-427, 584-588.

63 J. Łosowski, Kancelaria grodzka chetmska, s. 214.

64 Tamże, s. 323.

65 П. Кулаковський, Канцелярія Руської (Волинської) метрики, s. 19.

66 U. Augustyniak, Informacja i propaganda, s. 45.

67 CPAH Ukrainy we Lwowie, f. 9, op. 1, spr. 426, s. 2448-2450.

68 J. Łosowski, Kancelaria grodzka chetmska, s. 334.

69 CPAH Ukrainy we Lwowie, f. 13, op. 1, spr. 417, s. 1957-1958. 
sobów, za pomocą których rozpowszechniano treść uniwersału, rozszerzała zasięg społeczny odbiorców oficjalnej informacji.

Kolejne komponenty efektywności komunikacyjnej - „do kogo i w jakiej sytuacji przez niego przemawiano” - kształtowały się w procesie pisania tekstu. Powstaje pytanie, czy miało znaczenie, jakiej pozycji społecznej byli odbiorcy dokumentu oraz czy zależała od tego zawartość tekstu ${ }^{70}$. W przypadku uniwersałów dochodzimy do następujących wniosków: wygląd i treść uniwersałów królewskich skierowanych bezpośrednio do przedstawicieli stanu szlacheckiego (narracja tych uniwersałów była bardzo szczegółowa) $)^{71}$ różniła się od takich samych dokumentów skierowanych do przedstawicieli innych stanów. Przykładowo uniwersały „sejmowe”, „wojskowe” (te, którymi ogłaszano zebranie pospolitego ruszenia) i „finansowe” (jeśli dochody od podatku przeznaczano na misje dyplomatyczne) zawierają nie tylko rozkaz króla, wzywający do podporządkowania się jego woli, lub wzywający do uczestnictwa w określonym zjeździe, lecz również uzasadnienia informujące o przyczynach i powodach wydania tego czy innego rozporządzenia. Po pierwsze, opisy te zawierają szczegółowe wiadomości na temat sytuacji politycznej w państwie (możemy je traktować jako swoistą oficjalną „kronikę” życia politycznego Rzeczypospolitej), głównie ze względu na polityczne zaangażowanie szlachty. Ponadto Janusz Łosowski uważa, że uniwersały sejmowe wykorzystywano w roli „pośrednika” w przekazywaniu informacji między królem i szlachtą ${ }^{72}$. Po drugie, w uniwersałach propagowano ogólnopaństwowe wartości szlacheckie $^{73}$, które psychologicznie miały skłonić szlachtę do wykonania woli monarchy. Zwłaszcza rozpowszechniano ideę „Rzeczpospolitej - jako przedmurza chrześcijaństwa" ${ }^{\prime \prime 4}$, której celem było podkreślenie potrzeby obrony państwa przed zewnętrznymi wrogami, głównie atakami tureckimi i tatarskimi. Agresorów tych identyfikowano jako

70 W. Bryła, Komunikacja staropolska, s. 255.

71 Specyfika dokumentacji oficjalnej czasów nowożytnych polegała na tym, że właśnie narracja i dyspozycja miały największe znaczenie dla propagandy państwowej (W. Chorążyczewski, Nowożytny dokument królewski. Możliwości badawcze, [w:] Polska kancelaria królewska, s. 38).

72 J. Łosowski, Kancelaria grodzka chetmska, s. 211-217.

73 Chociaż ostatnie nie były obcymi i dla przedstawicieli innych warstw ówczesnego społeczeństwa, np. mieszczaństwo jeszcze wówczas nie uformowało swoich wartości, dlatego przyjmowało szlacheckie ideały za swoje (M. Bogucka, Miasta a życie polityczne w Polsce XVI-XVII w., [w:] Wtadza i spoleczeństwo w XVI i XVII w., Warszawa 1989, s. 45).

74 Ta sytuacja była rezultatem rozpowszechnienia chrześcijańskiego modelu pojmowania świata i Europy (Republiki Chrześcijańskiej), a jednocześnie idei wyższości Europy i Europejczyków (K. Maliszewski, Barokowe „Theatrum Mundi”. Uwagi o staropolskim obrazie świata na podstawie polskich gazet rękopiśmiennych, [w:] Staropolski ogląd świata, s. 161). 
wrogów Krzyża Świętego ${ }^{75}$, a wojnę z nimi często deklarowano jako walkę „o chwałę Bożą, o kościoły święte, żarliwość wolności, od przodków nabytej, conservatio i nad bracią swoją ginącą, nad niewinnego gminu chrześcijańskiego zgubą, niewolą pogań-

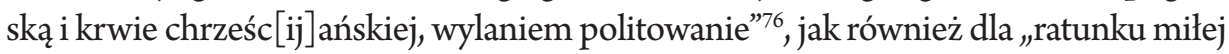
Ojczyzny, ...zaszczytu chwały Bożej, wiary świętej, świątnic pańskich, pignorum vestrorum..." ${ }^{\prime 7}$. Często idea walki z wrogami wiary łączyła się z ideologią walki o obronę „złotych wolności” od innowierców ${ }^{78}$ : „aby kościoły i świątnice pańskie, i prowincyje Korony Polskiej nie przychodzieły in abominationem desolationis i wolność ojczysta barbaricae nie podpadała servituti”79. Za panowania Michała Wiśniowieckiego skoordynowany udział w życiu politycznym państwa, szczególnie w sejmach, postrzegano jako ochronę „złotych wolności” szlacheckich ${ }^{80}$. Dlatego w uniwersałach uprzedzano, że szlachcice, którzy celowo sprzeciwiają się polityce dworu, będą odpowiadać przed Bogiem: „Będzie Bóg sprawiedliwy vindex na wszytkich, którzy consilia nobilitatis na sejmikach i zjazdach mieszali”»1. Uniwersały królewskie promowały również wartości fundamentalne, które kształtowały godność szlachecką, np. tak pisano o rycerskich cnotach szlachty: „klejnot szlachectwa jedyna cnoty recompensa, tak jest wysoko na całym świecie oszaczowany, ze go nie gnuśnością y podłą jaką industryją, ani trafunkiem, ale ryczerskiemi dziełami, krwią, a nawet i życiem nabywać” ${ }^{82}$. Te argumenty

75 „Przeciwko nieprzyjacielowi Krzyża Świętego” (CPAH Ukrainy we Lwowie, f. 13, op. 1, spr. 417, s. 1714-1720; f. 15, op. 1, spr. 186, s. 1178-1181).

76 Tamże, f. 15, op. 1, spr. 186, s. 1009-1012; f. 17 (Sąd grodzki trembowelski), op. 1, spr. 143, s. $688-691$.

77 Tamże, f. 13, op. 1, spr. 417, s. 2069-2074; f. 15, op. 1, spr. 186, s. 1249-1255; f. 17, op. 1, spr.143, s. 695-698.

78 H. Olszewski, Ideologia Rzeczypospolitej - przedmurza chrześcijaństwa, [w:] Sejm w dawnej Rzeczypospolitej. Ustrój i idee, t. 2: Studia i rozprawy, Poznań 2002, s. 123.

79 CPAH Ukrainy we Lwowie, f. 9, op. 1, spr. 425, s. 2023-2025.

80 „Życzemy / \& per omnia sacra żądamy, nic nie wątpiąc, że uprzejm[ość] i wiern[ość] w[asza] uważywszy następujące pericula, pleno pro conservatione praw / swobód / i fortun swoich / zelo concurrere do tego / i zabieżeć istis, które się dzieją przez rwanie sejmów, / zechcecie inconvenientiis, przez które in ultimum, czego strzeż Boże, / Ojczyzna ta musiałaby devenire discrimen” (tamże, f. 9, op. 1, spr. 422, s. 67-69). W uniwersałach Michała Wiśniowieckiego często powtarzano apele o pomyślne przeprowadzenie sejmu, co miało stanowić gwarancję skutecznej obrony kraju oraz uchronienia praw i swobód (tamże, f. 9, op. 1, spr. 423, s. 1711-1713).

81 Tamże, f. 9, op. 1, spr. 426, s. 2448-2450.

82 Tamże, f. 9, op. 1, spr. 449, s. 182-187; f. 13, op. 1, spr. 442, s. 391-392; f. 7 (Sąd grodzki żydaczowski), op. 1, spr. 69 , s. $182-187$; f. 5, op. 1, spr. 187, s. 45-48. 
miały na celu zdobyć poparcie szlachty w prowadzeniu działań wojennych. Chociaż ideały szlacheckości w ciągu XVII w. zmieniały się ${ }^{83}$, za pierwszorzędne nadal uważano odwagę i rycerskość ${ }^{84}$. Więc opis tchórzliwości rycerza, jego ucieczki z pola bitwy zawierał elementy potępienia i wskazania na konieczność prawnej walki z takimi żołnierzami ${ }^{85}$. Uniwersały królewskie były oficjalnymi źródłami informacji, dlatego promowano w nich ideę uległości króla przed potrzebami państwa i jego poddanych, dla których był ojcem: „ojcowskie serce nasze publicznym in victimam oddane potrzebom" ${ }^{" 86}$. Zwłaszcza w uniwersałach króla Jana III nieustannie pisano o aktywnym udziale w działaniach wojennych: „a sami na koniec ... osobą naszą wybieramy się do obozu i ochotnie vitam et sanguinem na chwałę Bożą za miełą Ojczyznę devovemus" ${ }^{87}$; „mężnie stojemy, pracowicie trwamy i wszytkim g[e]n[e]rosis pectoribus przykład z siebie dawamy" ${ }^{\prime 8}$. Natomiast uniwersały dotyczące rozporządzeń dla innych, politycznie nieaktywnych stanów społecznych Rzeczypospolitej, zawierają jedynie krótką informację o dokładnej przyczynie ich wystawienia i ogłoszenia.

Kolejna część efektywności komunikatywnej dokumentu - „w jakim celu mówiono" - wpływa na wybór pewnego sposobu językowego realizacji zamiaru monarchy ${ }^{89}$. Po pierwsze, gdy król i jego dwór starali się przekonać stan szlachecki co do konieczności wykonania pewnych poleceń - cytowano liczne argumenty, które

83 Większość szlachty zaczęła identyfikować się z ziemiaństwem, bo tylko ta działalność dawała realne dochody. Ta tendencja była następstwem licznych wojen w XVII w., przez co zmniejszało się pragnienie szlachty do udziału w kampaniach wojskowych, a wojsko straciło swój szlachecki charakter (R. Gałaj, Życie codzienne szlachty polskiej w okresie sarmatyzmu, Szczecin 1998, s. 102). Chociaż ta tendencja nie była aż tak popularna wśród szlachty województwa ruskiego, gdzie wciąż panowały wartości rycerskie. Wyjaśnić to można chociażby terytorialną bliskością do granicy państwa, gdzie cnoty rycerskie identyfikowano z obowiązkiem „chronienia samych siebie” (tamże, s. 106).

84 J. Tazbir, Wzorce osobowe szlachty polskiej w XVII wieku, Kwartalnik Historyczny 83 (1976), nr 4, s. 788.

85 „Wszym, ieżeli czy to stawali i ochota starożytna polska ieżeliby w nich zniknęła, tedy takich wszytkich pro desertoribus castroru[m] et profugis poczytawszy, od zasług, od uczciwego odsądzać rozkazujemy, et po[e]nas legum przeciwko takowym zbiegom extendere nie zaniechamy" (CPAH Ukrainy we Lwowie, f. 9, op. 1, spr. 431, s. 1473-1474; f. 13, op. 1, spr. 419, s. 1310-1312).

86 Tamże, f. 9, op. 1, spr. 452, s. 3100-3102.

87 Tamże, f. 13, op. 1, spr. 417, s. 1714-1720; f. 15, op. 1, spr. 186, s. 1178-1181.

88 Tamże, f. 9, op. 1, spr. 431, s. 1276-1278; f. 5, op. 1, spr. 176, s. 1458-1462.

89 W. Bryła, Komunikacja staropolska, s. 255. 
miały zachęcić szlachtę do ich realizacji. Takich argumentów nie odnotowano w uniwersałach skierowanych do innych grup społecznych, widocznie przyjmowano, że są one zobowiązane wykonywać rozkaz władcy bez obszerniejszej argumentacji. Po drugie, uniwersały królewskie - w przeciwieństwie do innych aktów królewskich (pisanych w języku łacińskim) - pisano głównie w języku polskim (odnotowano tylko dwa wyjątki $)^{90}$. Dzięki temu zwiększano zasięg społeczny osób, które mogły bez większych problemów zrozumieć treść dokumentu. Dodajmy, że ludność województwa ruskiego oraz innych ukraińskich terenów Rzeczypospolitej dobrze rozumiała język polski. Świadczy o tym chociażby fakt, że utwory poetyckie ówczesnych studentów Akademii Kijowsko-Mohylańskiej łatwo było odczytać zarówno po ukraińsku, jak i po polsku, bez zmian w słownictwie ${ }^{91}$. Po trzecie, aby dokument trafił do odbiorcy, język musiał być uproszczony i emocjonalny, czyli taki, który wpływał na wyobraźnię $e^{92}$. Właśnie taki sposób narracji stosowano przy uroczystym ogłoszeniu ogólnopaństwowych uniwersałów przez woźnego koronnego.

Oprócz wymienionych elementów na efektywność komunikacyjną wpływa zawartość informacyjna dokumentu. Dzięki uniwersałom dwór królewski rozpowszechniał wśród ludności różnorodne informacje, dotyczące nie tylko problemów państwowych, ale również lokalnych kwestii społecznych, religijnych oraz ekonomicznych. Chociaż analizowane akta grodzkie nie zawierają wszystkich uniwersalów adresowanych do mieszkańców województwa ruskiego, lecz zawartej w nich informacji wystarcza dla ogólnego zrozumienia różnych aspektów polityki państwa i sytuacji w Rzeczypospolitej w ostatnim trzydziestoleciu XVII w. Jednak dostępność informacji w aktach nie może świadczyć o jej dostarczeniu do wszystkich adresatów (czy również do innych odbiorców) oraz o przyjęciu i wykonaniu opublikowanych rozkazów i poleceń królewskich. Chcąc zwiększyć efektywność komunikatywną uniwersałów, w ich treści często wspominało się o wartościach szlacheckich. W trakcie wojny wiadomości zawarte w uniwersałach miały ubezpieczyć ludność przed wrogami bez względu na status społeczny. Szczególnie istotne były wezwania ludności województwa ruskiego do udziału w kampaniach wojskowych, ponieważ ziemie te były

90 CPAH Ukrainy we Lwowie, f. 5, op. 1, spr. 177, s. 247-251; f. 13, op. 1, spr. 420, s. 586-590; f. 15 , op. 1, spr. 188, s. 229-232.

91 І. Шевченко, Україна між Сходом і Заходом: Нариси з історії культури до початку XVIII cm., реА. А. Ясіновські, переклаА з англ. М. Габлевич, Аьвів 2001, s. 129.

92 A. Czarniecka, Nikt nie stucha mnie za życia... Jan III Sobieski w walce z opozycyjna propaganda, Warszawa 2009, s. 21. 
terenami lub graniczyły z terenami, gdzie miały miejsce główne działania wojenne. W skutek tego ludność pochodząca z tych obszarów żyła w nieustającym poczuciu zagrożenia ${ }^{93}$, w niektórych uniwersałach zaznaczano, że podczas ataku wroga ludzie powinni ukrywać się w pobliskich twierdzach ${ }^{94}$. Uniwersały były częścią systemu ochrony ludności cywilnej nie tylko od wojsk nieprzyjaciela. Niektóre dokumenty powtarzały i promowały postanowienia ówczesnych konstytucji: „Disciplina militaris”, „Immunitas dóbr szlacheckich” / „Securitas dóbr ziemskich”96 lub „Ekonomie Krola Jego M[iłoś] ci” ${ }^{97}$, w których wojskowym zabraniano czynić krzywdy i szkody ludności cywilnej oraz „sprawiedliwie” postępować wobec swawolnych żołnierzy ${ }^{98}$.

Podsumowując warto zauważyć, że dwór królewski we wczesnonowożytnej Rzeczypospolitej, dostosowując się do potrzeb informacyjnych społeczeństwa, stworzył i spopularyzował własne środki masowego przekazu informacji. Ważne miejsce wśród nich zajmowały uniwersały królewskie, których głównym celem było opublikowanie najważniejszych decyzji króla. W celu zwiększenia efektywności komunikatywnej uniwersałów dwór królewski wykorzystywał wszystkie dostępne narzędzia, takie jak: oficjalne pochodzenie, autentyczność, rozpowszechnienie treści przez urzędy państwowe $\mathrm{w}$ terenie, pojemność informacyjną oraz propagandę wartości w uniwersałach adresowanych do szlachty, używanie języka polskiego, jako najbardziej rozpowszechnionego. Trudno jednak stwierdzić czy efektywność komunikatywna uniwersałów skierowanych do ludności województwa ruskiego była wystarczająca, aby zadowolić potrzeby dworu królewskiego i państwa. Fakt, że ogłaszane w uniwersałach nakazy i wezwania nie zawsze były wykonywane, może świadczyć, że nie do końca.

93 K. Maliszewski, Problematyka turecka, s. 104.

94 CPAH Ukrainy we Lwowie, f. 9, op. 1, spr. 431, s. 1547-1550; spr. 433, s. 1032-1033; f. 5, op. 1, spr. 176, s. 1796-1799.

95 Volumina legum. Przedruk zbioru praw staraniem xx. Pijarów w Warszawie, t. 5, Petersburg 1860 , s. $174,320$.

96 Tamże, s. 138-139, 223, 321, 372.

97 Tamże, s. 67, 189-190.

98 Na terenie województwa ruskiego takie uniwersały dotyczyły bezpieczeństwa ekonomii samborskiej (CPAH Ukrainy we Lwowie, f. 13, op. 1, spr. 418, s. 39-41; spr. 451, s. 2150-2151), Przemyśla (tamże, f. 13, op. 1, spr. 419, s. 1860-1863) oraz Lwowa (tamże, f. 9, op. 1, spr. 426, s. 2585-2587). 
Nadesłany: 7 V 2017

Nadesłany po poprawkach recenzyjnych: 20 VIII 2017

Zaakceptowany: 1 IX 2017

mgr МАрТА ОНИСьків

КафеАра Аавньої історії України та архівознавства

Історичний факультет

$\Lambda$ ьвівський національний університет імені Івана Франка

вук. Університетська, 1

Аьвів 79000

martamn9@gmail.com

\section{Communicative effectiveness of royal universals in the last three dec- ades of the seventeenth century (based on the relational books of the township of the Ruthenian region)}

Royal universal is researched as mass communication tool at the paper. The purpose of the paper is to determine the level of communicative efficiency of the royal universal for the early modern polish society. For this the author found the elements of communicative efficiency of the document and applied them to the royal universales. As a result the author writes about significant, but not perfect, level of communicative efficiency of the royal universal. Technical elements of communicative efficiency of the royal universal had not always been used. Besides that, early modern polish society (especially nobility) did not comply with all orders, which were in the royal universales. 